\title{
HAEMATOLOGICAL PROFILE OF FRESHWATER FISH, CHANNA STRIATUS (BLOCH) UNDER THE STRESS OF ZINC SULPHATE
}

\author{
P. Pandari Reddy and G. Sunitha Devi" \\ mail: pandureddy29@gmail.com \\ Department of Zoology, University College of Science, \\ Osmania University, Hyderabad, 500 007, T.S., India.
}

\begin{abstract}
In the present investigation, Zinc Sulphate toxicity was evaluated on various haematological parameters in a fresh water air-breathing fish, Channa striatus. When exposed to sublethal concentrations $(15,20 \mathrm{and} 30 \mathrm{mg} / \mathrm{L})$ of Zinc Sulphate in water for a period of 10,20, 30 and 40days. At the end of 10, 20, 30 and 40days exposure periods, blood samples were collect from the control and experimental fish. The fish blood was assayed for selected haematological parameters, Haemoglobin (Hb), Red blood cells (RBC), Haematocrit (Hct) and White blood cells (WBC). The derived haematological indices of Mean cell volume (MCV), Mean cell Haemoglobin (MCH) and Mean cell Haemoglobin concentration (MCHC) were calculated. The fish, showed a haematological response after exposure (10,20, 30 and 40days) to 15, 20 and 30mg/L of Zinc Sulphate. There was a decrease in Haemoglobin content (Hb), Red blood cells (RBC), Haematocrit value (Hct) and Mean cell haemoglobin $(\mathrm{MCH})$. A significant increase was observed in WBC and Mean cell volume, Mean cell haemoglobin concentration. In conclusion, the alterations were observed indicate that haematological parameters can be used as an indicator of Zinc related stress in fish on exposure to elevated Zinc Sulphate levels.
\end{abstract}

KEYWORDS: Channa striatus, Zinc Sulphate, sublethal, Haematological parameters.

\section{INTRODUCTION}

The pollution of the environment with toxic substances has been increased in recent years as a result of the rapid growth of industries ${ }^{1}$. The industrial discharges containing toxic and hazardous substances, including heavy metals contribute tremendously to the pollution of aquatic ecosystem $^{13}$. The aquatic environment has been always subjected to different types of pollutants of industrial, agricultural and domestic wastes and severely affect the aquatic organisms ${ }^{7}$.

The contamination of the aquatic systems with heavy metals from natural, anthropogenic sources has become a global problem which poses a threat to ecosystems and natural communities ${ }^{12}$. Increased discharge of heavy metals into natural aquatic ecosystems can expose aquatic organisms to unnaturally high levels of these metals $^{26}$. The heavy metal toxicants were accumulated in the fish through general body surface which affects their life support system. Once these toxic substance enters into body, they damage and weaken the mechanism concerned leading to physiological, pathological and biochemical disorders ${ }^{3}$.

Zinc is the second most abundant trace element after $\mathrm{Fe}$ and is an essential trace element and micronutrient in living organisms, found almost in every cell and being involved in nucleic acid synthesis and occurs in many enzymes. Additionally, Zn is involved in more complicated functions, 
such as the immune system, neurotransmission and cell signalling ${ }^{20}$. Although, small quantity of Zinc are required for the normal development and metabolism, but if its level exceeds the physiological requirements, it can act as a toxicant ${ }^{27}$. The deficiency of Zinc has many symptoms including hindered growth, hypogonadism in males, neurosensory impairments and cell-mediated immunological malfunction ${ }^{10}$.

Haematology of fish is often determined as an index of their general health status. Haematological parameters are important patho-physiological indices and are important in diagnosing the structural and functional status of fish exposed to toxicants ${ }^{17}$. In recent years, for determining the effect of toxic substances during clinical diagnosis haematological parameters are used because of close association between the circulatory system and external environment ${ }^{33,28}$. Thus haematological alterations could be used as a warning system to indicate the presence of chronic toxicity of a toxicant in natural water.

\section{MATERIALS AND METHODS}

\section{Experimental Animals}

In the present study, Channa striatus weighing 26-28g used in the present study were procured from State Fisheries culture tanks. They were transported to the laboratory in oxygenated containers and treated with $\mathrm{KMnO}_{4}$ to avoid dermal infection and acclimatized to laboratory conditions for 15 days. The fish were fed with commercial feed once a day at a rate of $2 \%$ of body weight and temperature was maintained at $28 \pm 1^{\circ} \mathrm{C}$. Water in the containers was replaced by fresh water at every $24 \mathrm{~h}$. Before starting the experiment, $\mathrm{LC}_{50}$ value was calculated by Finney Probit Analysis method ${ }^{8}$. The $\mathrm{LC}_{50}$ was found as $120 \mathrm{mg} / \mathrm{L}$.

\section{Analytical Techniques}

Determination of $\mathrm{LC}_{50}$ at 96 hours by Finney Probit Analysis method ${ }^{8}$. The sublethal concentrations of Zinc Sulphate were selected for the investigation were $1 / 8^{\text {th }}$ of $\mathrm{LC}_{50}(15 \mathrm{mg} / \mathrm{L}), 1 / 6^{\text {th }}$ of $\mathrm{LC}_{50}(20 \mathrm{mg} /$ $\mathrm{L})$ and $1 / 4^{\text {th }}$ of $\mathrm{LC}_{50}(30 \mathrm{mg} / \mathrm{L})$. Haemoglobin (HB) was estimated by Cyanomethemoglobin method ${ }^{17}$. Red blood cell count (RBC) and White blood cell count (WBC) were estimated by Haemocytometer method $^{25}$. Haematocrit (Hct) was estimated by Wintrobe tube method ${ }^{32}$. Red Cell Indices were calculated from $\mathrm{Hb}$ Concentration, $\mathrm{Hct}$ percentage and RBC count ${ }^{6}$.

\section{Statistical Analysis}

Effects of Sublethal Concentrations $(15 \mathrm{mg} / \mathrm{L}, 20 \mathrm{mg} / \mathrm{L}$ and $30 \mathrm{mg} / \mathrm{L})$ of Zinc Sulphate for 10, 20, 30 and 40days of exposure on haematological parameters of fish, Channa striatus, were studied. The alterations in haematological parameters such as haemoglobin, red blood cells, white blood cells, haematocrit, red cell indices in terms of SEM(Mean \pm SE) along with Control. The results were statistically analysed by Student's t-test, all the data was presented as Mean \pm SE. For each experimental treatment, three replicates were 
taken. For each replicate, under each treatment mean was calculated. The mean values thus obtained were used to calculate experimental treatment Mean and standard errors of mean. P-values were determined using the t-statistics and denoted as NSNot Significant; * $\mathrm{P}<0.05$, ** $\mathrm{P}<0.01$, $* * * \mathrm{P}<0.001$.

\section{RESULTS AND DISCUSSIONS}

Table-1 and Figure-1 Revealed that the changes in haemoglobin of the blood of fish channa striatus exposed to sublethal concentrations of $\mathrm{ZnSO}_{4}$ upto 40 days. The haemoglobin content was decreased throughout the study period showing a minimum percent decrease of -2.39 at the end of $10^{\text {th }}$ day and a maximum percent decrease of -19.49 at the end of $40^{\text {th }}$ day. The decrease was more at higher concentration $(30 \mathrm{mg} / \mathrm{L})$ and higher duration (40days) when compared to the control. The alterations in red blood cell count (RBC) of the blood of fish, Channa striatus exposed to sublethal concentration of $\mathrm{ZnSO}_{4}$ upto 40days, shown in table- 2 and figure- 2 . The RBC count was decreased throughout the study period when compared to the control showing a minimum percent decrease of 12.21 at the end of $10^{\text {th }}$ day and a maximum percent decrease of -31.88 at the end of $40^{\text {th }}$ day. The decrease was more at higher concentration $(30 \mathrm{mg} / \mathrm{L})$ and higher duration (40days).

Table- 3 and Figure- 3 expressed the changes in White blood cell count was elevated showing a minimum percent increase of 6.72 at the end of the $10^{\text {th }}$ day and a maximum percent increase 24.07 at the end of $40^{\text {th }}$ day. The significant increase was more at higher concentration $(30 \mathrm{mg} / \mathrm{L})$ and higher duration (40days) when compared to control. Table-4 and Figure-4 represented the data on changes in the haematocrit values of the fish channa striatus exposed to sublethal concentrations of $\mathrm{ZnSO}_{4}$ upto 40days. The haematocrit values showing a minimum percent decrease of -1.19 at the end of $10^{\text {th }}$ day and a maximum percent decrease -15.10 at the end of $40^{\text {th }}$ day. The decrease was more at higher concentration and higher duration when compared to control.

Table-5 and Figure-5 revealed the changes in Mean cell volume (MCV) of the blood of fish, Channa striatus exposed to sublethal concentration of $\mathrm{ZnSO}_{4}$ upto 40days. The MCV was increased throughout the study period when compared to the control showing a minimum percent increase of 1.14 at the end of $10^{\text {th }}$ day and a maximum percent increase of 5.01 at the end of $40^{\text {th }}$ day. The increase was more at higher concentrations $(30 \mathrm{mg} / \mathrm{L})$ and higher duration compared to control.

Table- 6 and Figure- 6 represented the changes in the Mean cell haemoglobin $(\mathrm{MCH})$ was decreased throughout the study period shows a minimum percent decrease of -1.01 at the end of $10^{\text {th }}$ day and a maximum percent decrease of -11.53 at the end of $40^{\text {th }}$ day. The decrease was more at higher concentration and higher duration when compared to control. Table- 7 and 
Figure-7 revealed that the changes in Mean cell haemoglobin concentration (MCHC) of the blood of fish, Channa striatus exposed to sublethal concentrations of $\mathrm{ZnSO}_{4}$ upto 40days. The MCHC was increased throughout the study period when compared to control showing a minimum percent increase of 3.33 at the end of $10^{\text {th }}$ day and a maximum percent increase of 16.56 at the end of $40^{\text {th }}$ day. The increase was more at higher concentration $(30 \mathrm{mg} / \mathrm{L})$ and higher duration (40days).

Table-1: Alterations in Haemoglobin (HB) of Channa striatus exposed to sublethal concentrations of Zinc Sulphate compared to control (Mean \pm SE)

\begin{tabular}{|c|c|c|c|c|c|}
\hline \multirow{2}{*}{\multicolumn{2}{|c|}{$\begin{array}{l}\text { Concentration of } \\
\mathrm{ZnSO}_{4}\end{array}$}} & \multicolumn{4}{|c|}{ Experimental Days } \\
\hline & & \multirow{2}{*}{$\begin{array}{c}10 \text { days } \\
13.190 \\
\pm 0.158\end{array}$} & \multirow{2}{*}{$\begin{array}{c}20 \text { days } \\
13.200 \\
\pm 0.219\end{array}$} & \multirow{2}{*}{$\begin{array}{c}30 \text { days } \\
13.210 \\
\pm 0.236\end{array}$} & \multirow{2}{*}{$\begin{array}{c}40 \text { days } \\
13.210 \\
\pm 0.243\end{array}$} \\
\hline Control & $\begin{array}{l}\text { Mean } \\
\text { SE }\end{array}$ & & & & \\
\hline $15 \mathrm{mg} / \mathrm{L}$ & $\begin{array}{l}\text { Mean } \\
\text { SE } \\
\% \mathrm{~V}\end{array}$ & $\begin{array}{c}12.880^{\mathrm{NS}} \\
\pm 0.314 \\
-2.39\end{array}$ & $\begin{array}{c}12.580 * \\
\pm 0.182 \\
-4.69\end{array}$ & $\begin{array}{c}12.470 * \\
\pm 0.22 \\
-5.54\end{array}$ & $\begin{array}{c}12.420^{*} \\
\pm 0.216 \\
-5.92\end{array}$ \\
\hline $20 \mathrm{mg} / \mathrm{L}$ & $\begin{array}{l}\text { Mean } \\
\text { SE } \\
\% \mathrm{~V}\end{array}$ & $\begin{array}{c}12.610^{*} \\
\pm 0.220 \\
-4.44\end{array}$ & $\begin{array}{c}11.960 * * \\
\pm 0.173 \\
-9.38\end{array}$ & $\begin{array}{c}11.920 * * \\
\pm 0.189 \\
-9.69\end{array}$ & $\begin{array}{c}11.880 * * \\
\pm 0.263 \\
-10.01\end{array}$ \\
\hline $30 \mathrm{mg} / \mathrm{l}$ & $\begin{array}{l}\text { Mean } \\
\text { SE } \\
\% \mathrm{~V}\end{array}$ & $\begin{array}{c}11.670 * * \\
\pm 0.191 \\
-11.55\end{array}$ & $\begin{array}{c}10.880 * * * \\
\pm 0.171 \\
-17.57\end{array}$ & $\begin{array}{c}10.740 * * * \\
\pm 0.208 \\
-18.62\end{array}$ & $\begin{array}{c}10.630 * * * \\
\pm 0.251 \\
-19.49\end{array}$ \\
\hline
\end{tabular}

Each value is the Mean $\pm \mathrm{SE}$ of six individual observations.

$\mathrm{The} \mathrm{Hb}$ values are expressed as gram / deciliter $(\mathrm{g} / \mathrm{dL})$ in fish blood.

SE- Standard Error; \%V-Percent variation; NS: Not Significant; $* \mathrm{P}<0.05$; ** $\mathrm{P}<0.01$; $* * * \mathrm{P}<0.001$ 
Figure-1: Haemoglobin content in Channa striatus exposed to sublethal concentrations of $\mathrm{ZnSO}_{4}$ compared to control

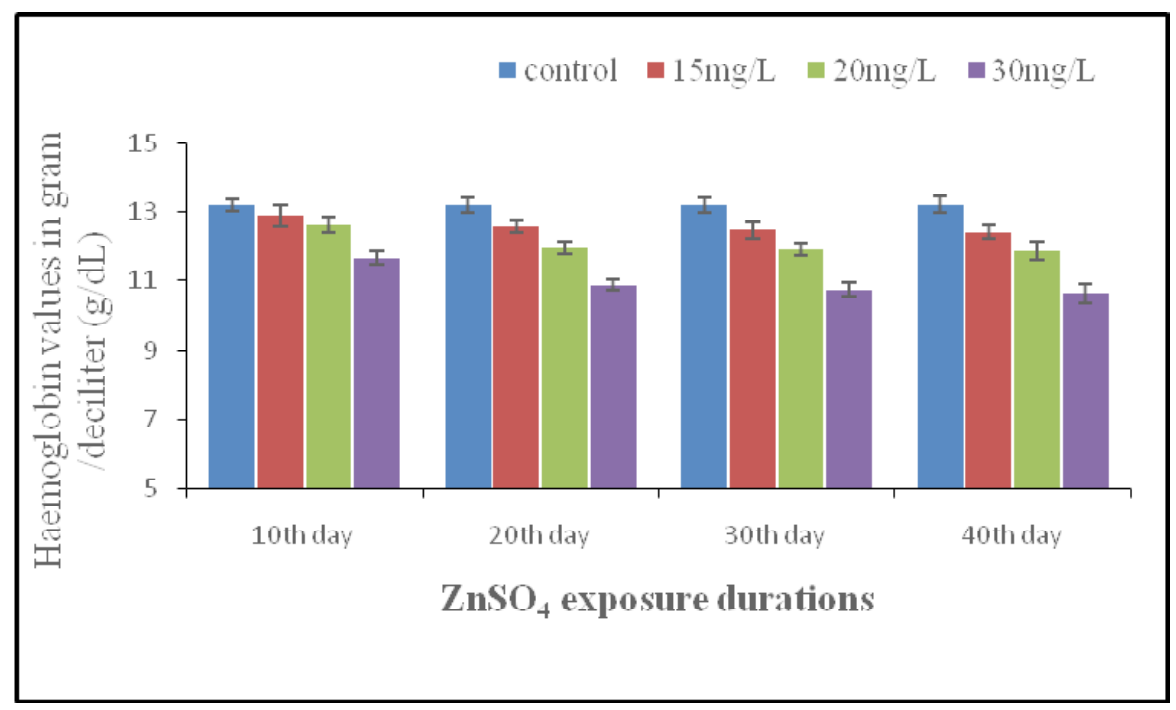

Table-2: Red Blood Cells (RBC) Count of Channa striatus exposed to sublethal concentrations of Zinc Sulphate compared to control. (Mean \pm SE)

\begin{tabular}{|c|c|c|c|c|c|}
\hline \multirow{2}{*}{\multicolumn{2}{|c|}{$\begin{array}{l}\text { Concentration of } \\
\mathrm{ZnSO}_{4}\end{array}$}} & \multicolumn{4}{|c|}{ Experimental Days } \\
\hline & & 10 days & 20 days & 30 days & 40 days \\
\hline Control & $\begin{array}{l}\text { Mean } \\
\text { SE }\end{array}$ & $\begin{array}{c}3.660 \\
\pm 0.196\end{array}$ & $\begin{array}{c}3.630 \\
\pm 0.243\end{array}$ & $\begin{array}{c}3.600 \\
\pm 0.153\end{array}$ & $\begin{array}{c}3.600 \\
\pm 0.148\end{array}$ \\
\hline $15 \mathrm{mg} / \mathrm{L}$ & $\begin{array}{l}\text { Mean } \\
\text { SE } \\
\% \mathrm{~V}\end{array}$ & $\begin{array}{l}3.220^{\mathrm{NS}} \\
\pm 0.294 \\
-12.21\end{array}$ & $\begin{array}{l}3.110^{\mathrm{NS}} \\
\pm 0.177 \\
-14.49\end{array}$ & $\begin{array}{l}3.060^{*} \\
\pm 0.212 \\
-15.11\end{array}$ & $\begin{array}{l}2.980^{*} \\
\pm 0.103 \\
-17.45\end{array}$ \\
\hline $20 \mathrm{mg} / \mathrm{L}$ & $\begin{array}{l}\text { Mean } \\
\text { SE } \\
\% \mathrm{~V}\end{array}$ & $\begin{array}{l}2.810^{*} \\
\pm 0.222 \\
-23.39\end{array}$ & $\begin{array}{l}2.710^{* *} \\
\pm 0.196 \\
-25.44\end{array}$ & $\begin{array}{r}2.630 * * \\
\pm 0.179 \\
-27.04\end{array}$ & $\begin{array}{l}2.590 * * \\
\pm 0.149 \\
-28.14\end{array}$ \\
\hline 30mg/l & $\begin{array}{l}\text { Mean } \\
\text { SE } \\
\% \mathrm{~V}\end{array}$ & $\begin{array}{l}2.690^{*} \\
\pm 0.211 \\
-26.70\end{array}$ & $\begin{array}{l}2.600 * * \\
\pm 0.162 \\
-28.52\end{array}$ & $\begin{array}{l}2.520 * * \\
\pm 0.150 \\
-30.14\end{array}$ & $\begin{array}{r}2.460^{* * *} \\
\pm 0.145 \\
-31.88\end{array}$ \\
\hline
\end{tabular}

30mg/L Mean SE \%V

Each value is the Mean $\pm \mathrm{SE}$ of six individual observations.

The RBC values are expressed as millions $/ \mathrm{mm}^{3}\left(10^{6} / \mathrm{mm}^{3}\right)$ of fish blood. SE- Standard Error; \%V-Percent variation; NS: Not Significant; $* \mathrm{P}<0.05 ; * * \mathrm{P}<0.01$; *** $\mathrm{P}<0.001$ 
Figure-2: Red Blood Cells Count in Channa striatus exposed to sublethal concentrations of $\mathrm{ZnSO}_{4}$ compared to control

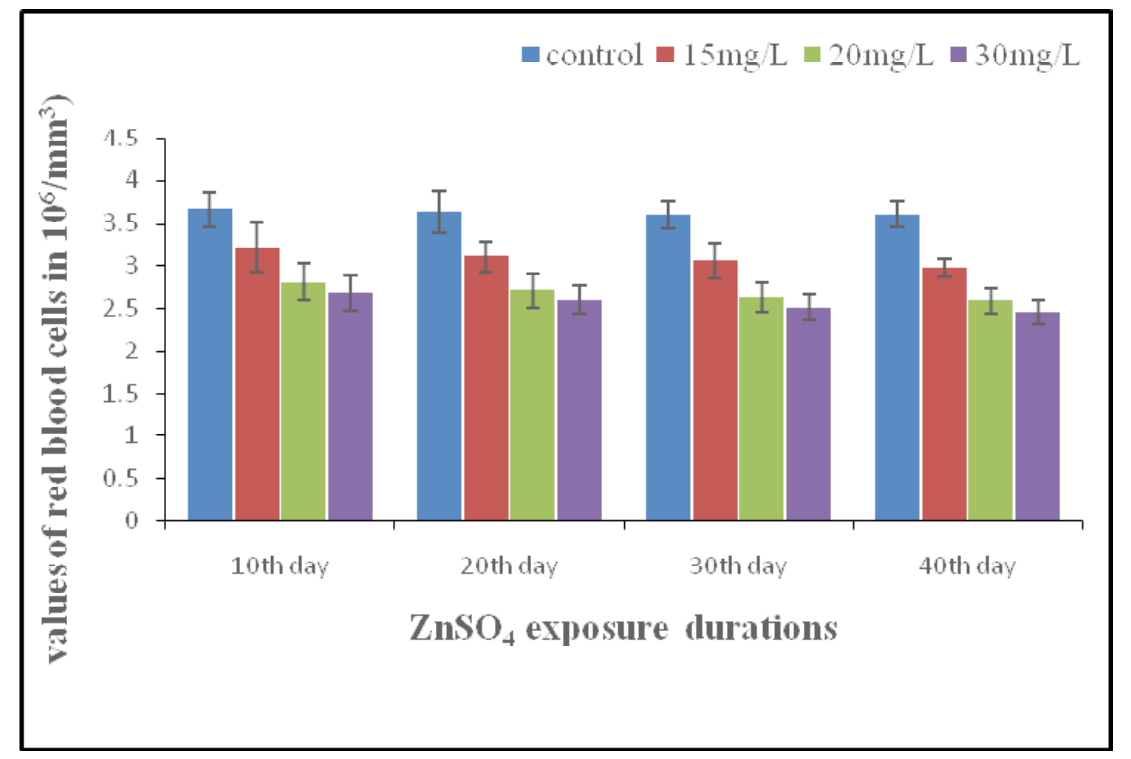

Table-3: White Blood Cell (WBC) count of Channa striatus exposed to sublethal concentrations of Zinc Sulphate compared to control. (Mean \pm SE)

\begin{tabular}{|l|l|c|c|c|c|}
\hline \multicolumn{2}{|l|}{$\begin{array}{l}\text { Concentration of } \\
\mathrm{ZnSO}_{4}\end{array}$} & \multicolumn{4}{|c|}{ Experimental Days } \\
\cline { 3 - 6 } Control & Mean & 4.280 & 20 days & 30 days & 40 days \\
& $\mathrm{SE}$ & \pm 0.109 & \pm .320 & 4.360 & 4.380 \\
& Mean & $4.570^{\mathrm{NS}}$ & $4.680^{\mathrm{NS}}$ & $4.780^{*}$ & $4.840^{*}$ \\
\hline $15 \mathrm{mg} / \mathrm{L}$ & $\mathrm{SE}$ & \pm 0.167 & \pm 0.217 & \pm 0.212 & \pm 0.236 \\
& $\% \mathrm{~V}$ & 6.72 & 8.41 & 9.81 & 10.66 \\
& Mean & $4.650^{*}$ & $4.830^{*}$ & $5.050^{* *}$ & $5.190^{* *}$ \\
& $\mathrm{SE}$ & \pm 0.147 & \pm 0.219 & \pm 0.194 & \pm 0.201 \\
& $\% \mathrm{mg} / \mathrm{L}$ & 8.66 & 11.97 & 16.01 & 18.55 \\
& Mean & $4.840^{*}$ & $5.010^{* *}$ & $5.200^{* *}$ & $5.430^{* * *}$ \\
& $\mathrm{SE}$ & \pm 0.222 & \pm 0.198 & \pm 0.207 & \pm 0.124 \\
\hline $30 \mathrm{mg} / \mathrm{l}$ & $\% \mathrm{~V}$ & 13.12 & 16.03 & 19.30 & 24.07 \\
& & & & \\
& &
\end{tabular}

Each value is the Mean \pm SE of six individual observations.

The WBC values are expressed as thousands $/ \mathrm{mm}^{3}\left(10^{3} / \mathrm{mm}^{3}\right)$ of fish blood.

SE- Standard Error; \%V-Percent variation; NS: Not Significant;* $\mathrm{P}<0.05$; ** $\mathrm{P}<0.01$; *** $\mathrm{P}<0.001$

88 • J. Adv. Zool. $2019: 40(1)$ 
Figure-3: White Blood Cells Count in Channa striatus exposed to sublethal concentrations of $\mathrm{ZnSO}_{4}$ compared to control

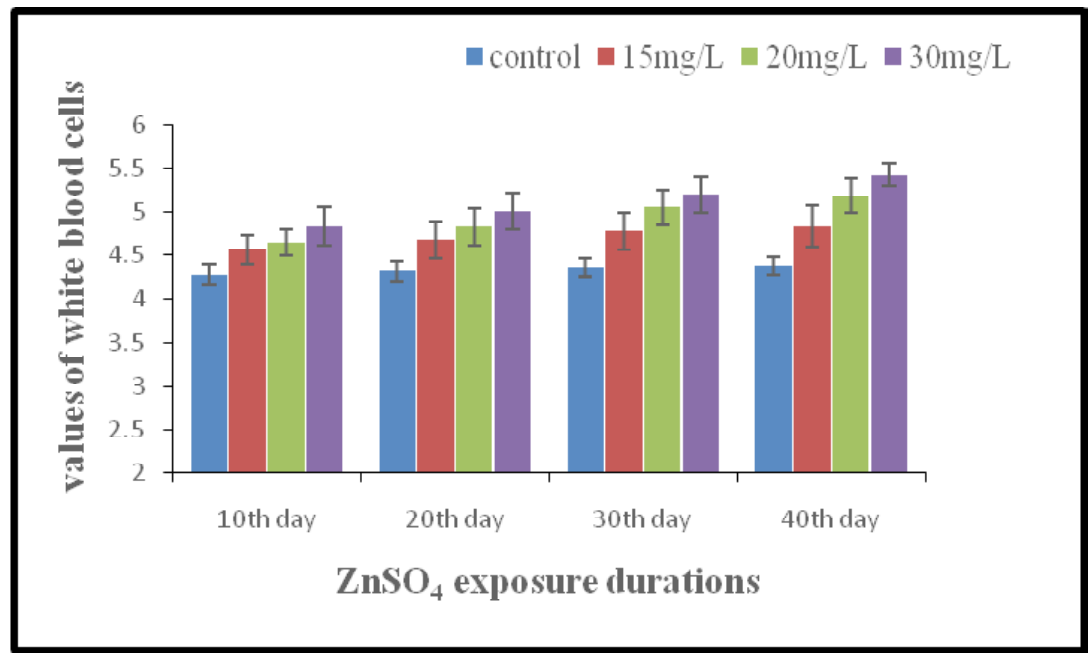

Table-4: Changes in Haematocrit (Hct) of Channa striatus exposed to sublethal concentrations of Zinc Sulphate compared to control. (Mean \pm SE)

\begin{tabular}{|l|l|c|c|c|c|}
\hline \multicolumn{2}{|l|}{$\begin{array}{l}\text { Concentration of } \\
\mathrm{ZnSO}_{4}\end{array}$} & \multicolumn{4}{|c|}{ Experimental Days } \\
\cline { 3 - 6 } Control & Mean & 39 days & 20 days & 30 days & 40 days \\
& $\mathrm{SE}$ & \pm 0.185 & 39.390 & 39.340 & 39.210 \\
& Mean & $39.250^{\mathrm{NS}}$ & $38.540^{*}$ & $38.370^{* *}$ & $36.160^{* * *}$ \\
\hline \multirow{2}{*}{$15 \mathrm{mg} / \mathrm{L}$} & $\mathrm{SE}$ & \pm 0.151 & \pm 0.213 & \pm 0.289 & \pm 0.199 \\
& SE & -1.19 & -2.15 & -2.97 & -5.23 \\
& $\% \mathrm{~V}$ & $38.110^{* *}$ & $37.180^{* *}$ & $36.910^{* * *}$ & $35.050^{* * * *}$ \\
& Mean & \pm 0.206 & \pm 0.199 & \pm 0.154 & \pm 0.301 \\
& $\mathrm{SE}$ & -3.45 & -5.61 & -5.85 & -10.61 \\
\hline \multirow{2}{*}{$30 \mathrm{mg} / \mathrm{L}$} & $\% \mathrm{~V}$ & $36.220^{* * *}$ & $35.480^{* * *}$ & $34.200^{* * *}$ & $33.290^{* * *}$ \\
& Mean & \pm 0.201 & \pm 0.396 & \pm 0.139 & \pm 0.181 \\
& $\mathrm{SE}$ & -8.23 & -9.93 & -12.68 & -15.10 \\
\hline
\end{tabular}

Each value is the Mean \pm SE of six individual observations.

The Haematocrit values are expressed as percentage $(\%)$ of fish blood.

SE- Standard Error; \%V-Percent variation; NS: Not Significant; * $\mathrm{P}<0.05$; ** $\mathrm{P}<0.01$; *** $\mathrm{P}<0.001$ 
Figure-4: Haematocrit values (\%) in Channa striatus exposed to various period treated at various sublethal doses of $\mathrm{ZnSO}_{4}$ compared to control

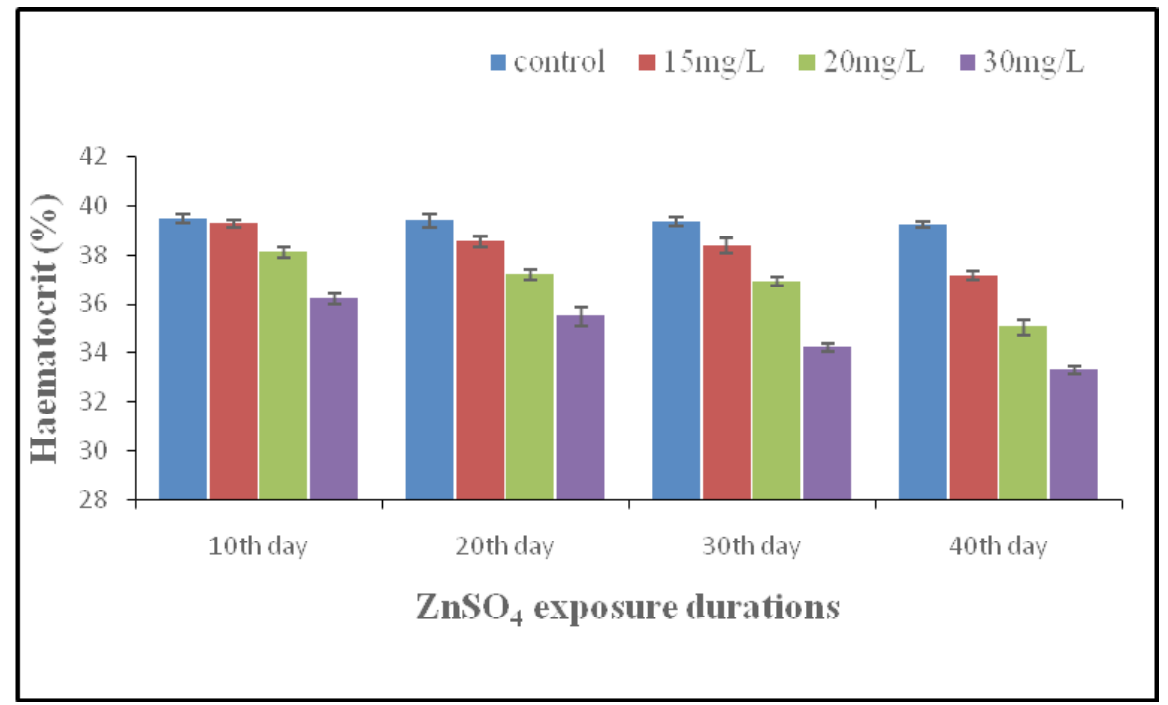

Table-5: Changes in Mean Cell Volume (MCV) of Channa striatus exposed to sublethal concentrations of Zinc Sulphate compared to control. (Mean \pm SE)

\begin{tabular}{|l|l|c|c|c|c|}
\hline \multicolumn{2}{|l|}{$\begin{array}{l}\text { Concentration of } \\
\mathrm{ZnSO}_{4}\end{array}$} & \multicolumn{4}{|c|}{ Experimental Days } \\
\cline { 3 - 6 } & & 10 days & 20 days & 30 days & 40 days \\
\hline Control & Mean & 118.800 & 118.580 & 118.910 & 119.650 \\
& $\mathrm{SE}$ & \pm 0.182 & \pm 0.200 & \pm 0.199 & \pm 0.209 \\
\hline $15 \mathrm{mg} / \mathrm{L}$ & Mean & $120.150^{*}$ & $120.540^{* *}$ & $120.680^{* *}$ & $123.220^{* * *}$ \\
& $\mathrm{SE}$ & \pm 0.592 & \pm 0.478 & \pm 0.288 & \pm 0.376 \\
& $\% \mathrm{~V}$ & 1.14 & 1.65 & 1.49 & 2.98 \\
\hline $20 \mathrm{mg} / \mathrm{L}$ & Mean & $120.360^{* *}$ & $122.310^{* * * *}$ & $122.910^{* * *}$ & $124.690^{* * *}$ \\
& $\mathrm{SE}$ & \pm 0.343 & \pm 0.300 & \pm 0.367 & \pm 0.349 \\
& $\% \mathrm{~V}$ & 2.15 & 3.34 & 3.36 & 4.21 \\
\hline $30 \mathrm{mg} / \mathrm{l}$ & Mean & $122.140^{* * *}$ & $124.290^{* * * *}$ & $124.720^{* * *}$ & $125.650^{* * *}$ \\
& $\mathrm{SE}$ & \pm 0.260 & \pm 0.370 & \pm 0.234 & \pm 0.262 \\
& $\% \mathrm{~V}$ & 2.81 & 4.82 & 4.89 & 5.01 \\
\hline
\end{tabular}

Each value is the Mean \pm SE of six individual observations.

The MCV values are expressed as $\left(\mu \mathrm{m}^{3}\right)$ in fish blood.

SE- Standard Error; \%V-Percent variation; NS: Not Significant; $\quad * \mathrm{P}<0.05$; ** $\mathrm{P}<0.01$; *** $\mathrm{P}<0.001$ 
Figure-5: Mean Cell Volume in Channa striatus exposed to sublethal concentrations of $\mathrm{ZnSO}_{4}$ compared to control

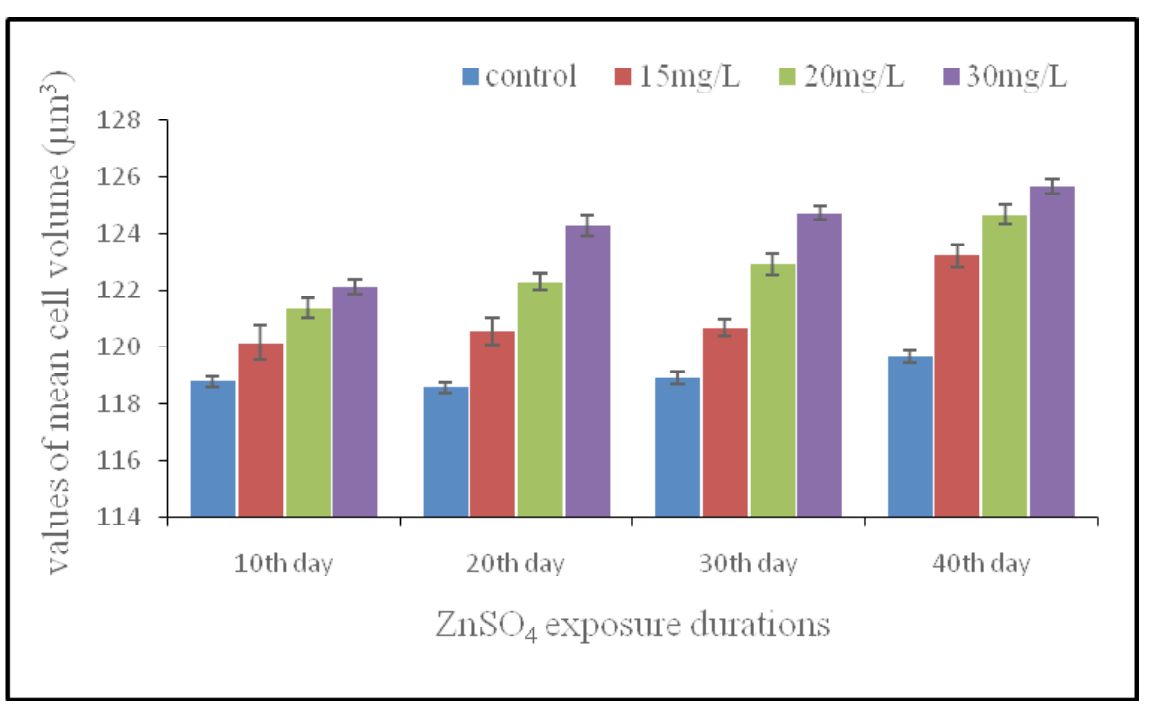

Table-6: Changes in Mean Cell Haemoglobin (MCH) of Channa striatus exposed to sublethal concentrations of Zinc Sulphate compared to control. (Mean \pm SE)

\begin{tabular}{|l|l|c|c|c|c|}
\hline \multicolumn{2}{|l|}{$\begin{array}{l}\text { Concentration of } \\
\mathrm{ZnSO}_{4}\end{array}$} & \multicolumn{4}{|c|}{ Experimental Days } \\
\cline { 3 - 6 } Control & Mean & 39 days & 20 days & 30 days & 40 days \\
& $\mathrm{SE}$ & \pm 0.216 & 39.430 & 39.560 & 39.450 \\
& Mean & $39.150^{\mathrm{NS}}$ & $38.880^{\mathrm{Ns}}$ & $38.640^{\mathrm{NS}}$ & $37.800^{*}$ \\
\hline \multirow{2}{*}{$5 \mathrm{mg} / \mathrm{L}$} & $\mathrm{N}$ & -245 & \pm 0.347 & \pm 0.296 & \pm 0.433 \\
& $\mathrm{SE}$ & -1.01 & -1.39 & -2.33 & -4.18 \\
& $\% \mathrm{~V}$ & $37.660^{* *}$ & $37.350^{* *}$ & $36.910^{* *}$ & $35.910^{* * * *}$ \\
& Mean & \pm 0.371 & \pm 0.311 & \pm 0.374 & \pm 0.367 \\
\hline $20 \mathrm{mg} / \mathrm{L}$ & -4.78 & -5.28 & -6.69 & -8.97 \\
& $\mathrm{SE}$ & $35.560^{* * *}$ & $35.240^{* * *}$ & $35.170^{* * *}$ & $34.900^{* * * *}$ \\
& $\% \mathrm{~V}$ & \pm 0.483 & \pm 0.357 & \pm 0.256 & \pm 0.342 \\
& Mean & -10.09 & -10.63 & -11.11 & -11.53 \\
\hline
\end{tabular}

Each value is the Mean \pm SE of six individual observations.

The $\mathrm{MCH}$ values are expressed as picogram (pg) in fish blood.

SE- Standard Error; \%V-Percent variation;

NS: Not Significant; $* \mathrm{P}<0.05 ; * * \mathrm{P}<0.01 ; * * * \mathrm{P}<0.001$ 
Figure-6: Mean Cell Haemoglobin in Channa striatus exposed to sublethal concentrations of $\mathrm{ZnSO}_{4}$ compared to control

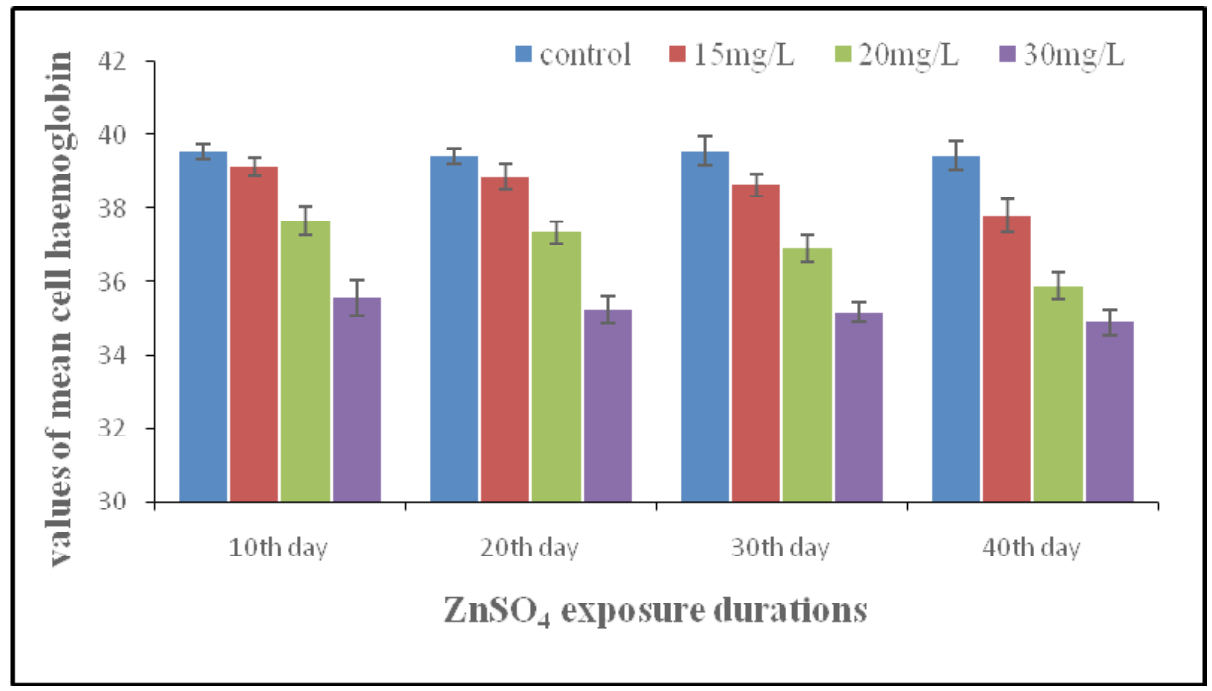

Table-7: Changes in Mean Cell Haemoglobin Concentration (MCHC) of Channa striatus exposed to sublethal concentrations of Zinc Sulphate compared to control. (Mean $\pm \mathrm{SE}$ )

\begin{tabular}{|l|l|c|c|c|c|}
\hline \multicolumn{2}{|l|}{$\begin{array}{l}\text { Concentration of } \\
\mathrm{ZnSO}_{4}\end{array}$} & \multicolumn{4}{|c|}{ Experimental Days } \\
\cline { 3 - 6 } Control & Mean & 33.370 & 33.360 & 33.340 & 33.390 \\
& $\mathrm{SE}$ & \pm 0.32 & \pm 0.32 & \pm 0.22 & \pm 0.37 \\
\hline \multirow{2}{*}{$15 \mathrm{mg} / \mathrm{L}$} & Mean & $34.480^{*}$ & $34.580^{* *}$ & $34.870^{* *}$ & $35.160^{* *}$ \\
& $\mathrm{SE}$ & \pm 0.37 & \pm 0.28 & \pm 0.36 & \pm 0.37 \\
& $\% \mathrm{~V}$ & 3.33 & 3.66 & 4.59 & 5.30 \\
\hline \multirow{2}{*}{$20 \mathrm{mg} / \mathrm{L}$} & Mean & $35.550^{* *}$ & $36.620^{* *}$ & $36.810^{* * *}$ & $37.750^{* * * *}$ \\
& $\mathrm{SE}$ & \pm 0.37 & \pm 0.40 & \pm 0.41 & \pm 0.41 \\
& $\% \mathrm{~V}$ & 6.53 & 9.77 & 10.41 & 13.06 \\
\hline $30 \mathrm{mg} / \mathrm{l}$ & Mean & $36.260^{* * * *}$ & $37.550^{* * *}$ & $37.640^{* * *}$ & $38.920^{* * *}$ \\
& $\mathrm{SE}$ & \pm 0.37 & \pm 0.42 & \pm 0.25 & \pm 0.36 \\
& $\% \mathrm{~V}$ & 8.66 & 12.56 & 12.91 & 16.56 \\
\hline
\end{tabular}

Each value is the Mean \pm SE of six individual observations.

The MCHC values are expressed as percentage (\%) in fish blood.

SE- Standard Error; \%V-Percent variation;

NS: Not Significant; $* \mathrm{P}<0.05 ; * * \mathrm{P}<0.01 ; * * * \mathrm{P}<0.001$ 
Figure-7: Mean Cell Haemoglobin Concentration in Channa striatus exposed to sublethal concentrations of $\mathrm{ZnSO}_{4}$ compared to control

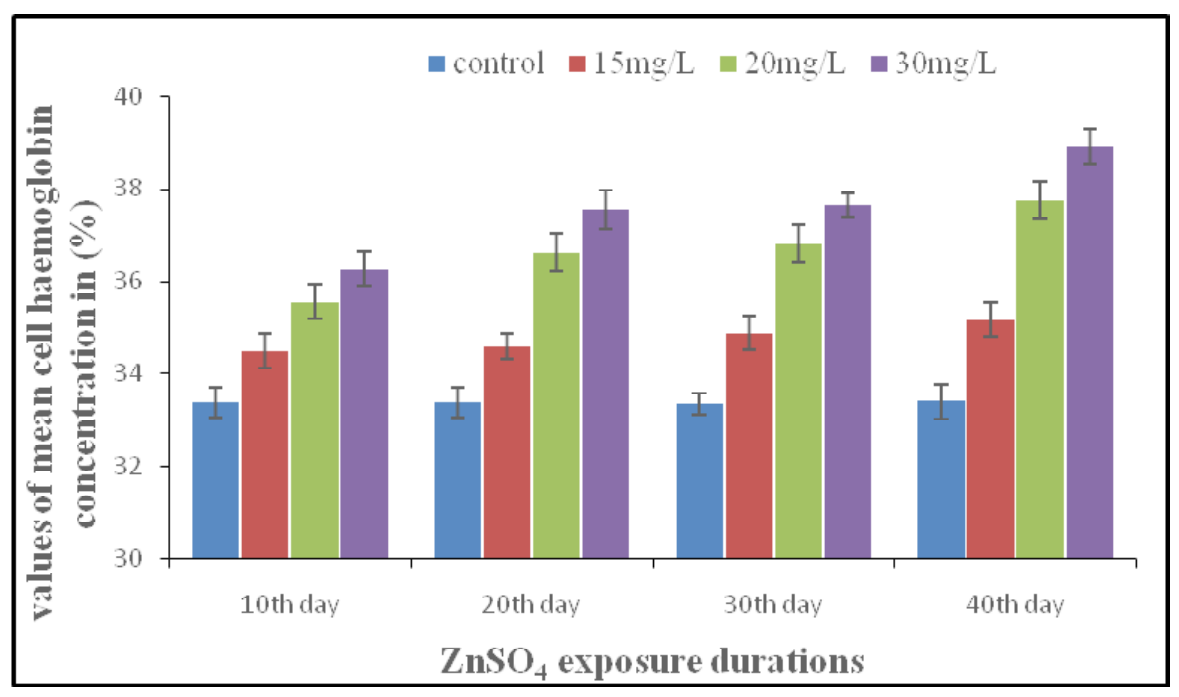

The contamination of aquatic environment by heavy metals are severely hazardous of their toxicity. Whether as a consequence of acute and chronic events constitutes additional source of stress for aquatic organisms. ${ }^{19}$ The alterations in haematological parameters of fish, Channa striatus exposed to different concentrations of Zinc Sulphate upto 40 days. ${ }^{23}$ Reported that toxicants and pollutants have significant effects, which can result in several physiological dysfunctions, in fish. Dysfunction in the fish induces changes in blood parameters possible as a result of blood water content. In the present investigation, similar alterations were observed in blood, Haemoglobin, RBC, Haematocrit and MCH levels of Channa striatus. The decrease was more at higher concentrations $(30 \mathrm{mg} / \mathrm{L})$ and higher duration (40days). The significant decrease in haemoglobin of Clarias gariepinus to sublethal concentration of Zinc has been reported by ${ }^{2}$. The reduction in red blood cell counts and haemoglobin (\%) was found to cause macrocytic anaemia as noticed in fishes by ${ }^{30}$.

The fall in red blood cell counts seemed to be the major factor for the reduction of haematocrit and mean cell haemoglobin ${ }^{4}$. The total erythrocytes count, haemoglobin and packed cell volume exhibited a steady and significant decrease with an increase in the duration of exposure to $10 \mathrm{ppm}$ nickel ${ }^{11,5}$. Chaturvedi and Agrawal (1993) reported that in fish's reduction of haematocrit (PCV) was due to lower red blood cell counts and this resulted in significantly higher ESR value. Haematological indices such as 
haemoglobin, haematocrit and red blood cell count have been reported to indicate secondary responses of an organism to irritants ${ }^{24}$.

The reduction in the haemoglobin and haematocrit values in the fish could also be attributed to the lysing of erythrocytes ${ }^{26}$. Thus significant reduction in these parameters is an indication of severe anemia. ${ }^{20}$ Have reported that the decrease in total $\mathrm{RBC}, \mathrm{Hb} \%$ and $\mathrm{PCV}$ in the, Heteropneustes fossilis after nickel sulphate treatment for 15days. The reduction in some haematological values indicated anaemia and it may be due to erythropoisis, haemosynthesis and osmaregulatary dysfunction or due to an increase in the rate of erythrocyte destruction in the haemopoitic organs ${ }^{15,27}$. The significant reduction in the mean cell haemoglobin $(\mathrm{MCH})$ may be due to the reduction in cellular blood iron, resulting in reduced oxygen carrying capacity of blood and eventually stimulating erythropoiesis ${ }^{12}$.

White Blood Cells (WBC), Mean cell Volume (MCV) and Mean Cell Haemoglobin Concentration (MCHC) were increased throughout the experimental durations. The increase was more at higher concentration $(30 \mathrm{mg} / \mathrm{L})$ and higher duration (40days). The increase in number of WBC may play an important role in immunological defence systems during exposure to toxicants like heavy metals ${ }^{16}$. The White Blood Cells (WBC) showed a gradual increase on exposure to chronic, sublethal dose of nickel for 60 days was reported by ${ }^{11}$. The increase in WBC on exposure to various heavy metals caused by liver dysfunction and depression. ${ }^{9}$ The values of mean cell volume (MCV) and mean cell haemoglobin concentrations (MCHC) were found to increase during macrocytic anaemia. ${ }^{26}$ Observed increased Mean cell volume (MCV) levels up to 30days exposure to different concentrations of Copper in Oreochromis mossambicus and suggested that macrocytic anemia due to reserve of erythropoiesis and in the rate of erythrocyte destruction in the haemopoietic organs. The values of MCHC and MCV content were higher in zinc exposed fish, Claris batrachus, when compared with the control $^{21}$. The values of MCV and MCHC were found to increase during macrocytic anemia $^{4}$.

\section{CONCLUSION}

The present study revealed that the alterations in haematological parameters of Channa striatus due to intoxication of Zinc Sulphate. Since majority of heavy metals are released cumulatively and regularly, through the industrial and human activities their residues are known to bio accumulate in the tissues of fish and other animals and transfer via food chain to the human bodies, they cause risk to the health of the people who consume these fish seems to be considerable. It is concluded that the utilization of Zinc Sulphate should be minimize and should create awareness among the people about the toxicity of Zinc Sulphate. 


\section{ACKNOWLEDGMENTS}

Authors would like to express great gratitude to Head, Department of Zoology, Osmania University, and Hyderabad. This study was financially supported by UGCBSR-Fellowship.

\section{REFERENCE}

1. Akpomie, K.G. and F.A. Dawodu, 2015. Treatment of an automobile effluent from heavy metals contamination by an ecofriendly montmorillonite. J. Adv. Res., 6: 1003-1013.

2. Annune P.A., S.O. Ebele, A.A. Olademeji, 1994a, Acute Toxicity of Cadmium to Juveniles of Clarias gariepinus (Teugels) and Oreochromis niloticus (Trewawas). J. Environ. Sci. Health, A29:1357-1365.

3. Arasta T., V.S. Bais and P.B. Thakur, 1999. Changes in selected biochemical parameters in liver and muscles of the fish, mystus vittatus exposed to Aldrin. Environ. Pollution. Management (Ed.V.S.Bais Creative Pub., Sagar, pp. 109-112.

4. Bomford, R.S., S. Masons and M. Swash, 1975. Hutchison's Clinical Method. The Macmillion Publishing Company. Inc N.Y.

5. Chaturvedi, L.D. and K. Agrawal, 1993. Haematological changes in Heteropneustes fossilis following exposure to alachor and roger. Ad. Bio., 12(2):85-92.

6. Dacie, J.V., S.M. Lewis, 2001. Practical haematology, 6th edn. ELBS and Churchill, Livingston comp clinpathol.

7. Farkas, A. and G. Mance, et al, 2000. Lakes and reservoirs. Research and Managament, 5: 272-279.

8. Finney, D.J., 1978. In: Statistical Methods in Biological Assay, 3rd ed., London, Griffin Press, pp. 508.

9. Goel, K.A., K. Gupta and M.L. Sharma, 1985. Haematological characteristic of
Heteropneustes fossilis under the stress of zinc. Indian J. Fish., 32:186-188.

10. Handy, R.D., T.S. Galloway, M.H. Depledge, 2003. A proposal for the use of biomarkers for the assessment of chronic pollution and in regulatory toxicology. Ecotoxicology, 12: 331-341.

11. Hodson, P.V., B.R. Blunt, D.J. Spray, 1978. Chronic toxicity of water borne lead and dietary lead to rainbow trout. (Balmo garnderi) in lake Ontario water. Water Res. 12:869-878.

12. Ibemenuga, Keziah Nwamaka. "Bioaccumulation and toxic effects of some heavy metals in freshwater fishes." Animal Research International, 10.3 (2013): 1792.

13. Woodling, J.D., S.F. Brinkman and B.J. Horu, 2001. Non-Uniform accumulation of cadmium and copper in kidneys of wild brown trout salmo trutta populations. Arch. Environ. Contam. Toxicol., 40:318-385.

14. Jenkins, F., J. Smith, et al., 2003. Effect of sublethal concentration of endosulfan on hematological and serum biochemical parameters in the carp, Cyprinus carpio. Bull. Environ. Contam. Toxicol., 70: 993-947.

15. Kori-Siakpere, O. and E.O. Ubogu, 2008. Sub lethal haematological effects of zinc on the freshwater fish, Heteroclarias sp. (Osteichthyes: Clariidae). Afr. J. Biotechnol., 7:2068-2073.

16. Larsen, H.N., S.F. Snieszko, 1961. Comparison of various methods of determination of haemoglobin in trout blood. Prog. Fish Cult., 23:8-17.

17. Maheswaran, R., A. Devapaul, S. Muralidharan, B. Velmurugan \& S. Ignacimuthu, 2008. Haematological studies of freshwater fish, Clarias batrachus (L.) exposed to mercuric chloride. IJIB, 2(1), pp. 49-54.

18. Kumar, Muneesh and Dharvinder Kumar, 2017. Toxic effects of zinc sulphate on haematological indices of freshwater catfish Clarias batrachus (Linn.). IJZS, 2(1);49-52.

19. Nanda, P. and M.K. Behera, 1996. Nickel 
induced changes in some haematobiochemical parameters of a cat fish Heteropneustes fossilis (Bloch)., 14(1): 8285.

20. Omoregie E, E.B.C. Ufodike, I.R. Keke, 1990. Tissue chemistry of Oreochromis nitoloticus exposed to sublethal concentrations of gammalin 20 and actellic 25EC. J. Aquat. Sci.; 5:33-36.

21. Rogers, J.T., J.G. Richards and C.M. Wood, 2003. Ionoregulatory disruption as the acute toxic mechanism for lead in the rainbow trout. Aquat. Toxicol., 64(2):215-234.

22. Rusia, V., S.K. Sood, 1992. Routine haematological tests. In: Medical laboratory technology. Mukerjee, K. L., ed. Tata McGraw Hill Publishing Company Limited, pp. 252-258.

23. Samprath, K., S. Velamnial, I.J. Kennedy, R. James, 1993. Haematological changes and their recovery in Oreochromis mossambicus as a function of exposure period and sublethal levels of Ekalus. Acta Hydrobiol., 35:73-83.

24. Seth, N., K.K. Saxena, 2003. Hematological responses in a freshwater fish, Channa punctatus due to fenvalerate. Bull. Environ.
Contam. Toxicol., 71:1192-1199.

25. Sharma, J. \& S. Langer, 2014. Effect of manganese on haematological parameters of fish, Garra gotyla gotyla. Journal of Entomology and Zoology Studies, 2(3):77-81.

26. Srivastava, S.K., D. Singh, S. Prakash and K.K. Ansari, 2007. Effect of sublethal concentration of distillery effluent on the haematological and biochemical parameters of Clarias batrachus (Linn.). Ecol. Env. \& Con., 13 (3):511-514.

27. Van Dyk, J.C., G.M. Pieterse and J.H.J. Van Vuren, 2007. Histological changes in the liver of Oreochromis mossambicus (Cichlidae) after exposure to cadmium and zinc. Ecotoxicology. Environ. Safety 66:432-440.

28. Wintrobe, M.M., 1981. Variation in size and haemoglobin concentration of erythrocyte in the blood of various vertebrates, Folia Haemato., 51:32-49.

29. Witeska, M., E. Kondera, M. Szymanska \& M. Ostrysz, 2010. Hematological changes in common carp (Cyprinus carpio L.) after short-term lead $(\mathrm{Pb})$ exposure. Polish Journal of Environmental Studies, 19(4), 825-831. 